\title{
KAJIAN KEMAMPUAN KONEKSI MATEMATIK SISWA SMP DI KOTA BANDUNG PADA MATERI ARITMETIKA SOSIAL
}

\author{
Nurhasanah $^{1}$, Devi Yuliani ${ }^{2}$, Eva Dwi Minarti $^{3}$, Euis Eti Rohaeti ${ }^{4}$ \\ 1,2,3,4 IKIPSiliwangi Bandung \\ 1nurhasnah87@yahoo.com, ${ }^{2}$ deviyuliani77@gmail.com, ${ }^{3}$ studentm4th@gmail.com, ${ }^{4}$ e2rht@yahoo.com
}

\begin{abstract}
The ability of mathematical connections is an essential skill that must be mastered by high school students, as it will help master understanding of meaningful concepts and help solve mathematical problems through the interrelationship between mathematical concepts and between mathematical concepts and concepts in other disciplines even with applications in real-life students. This study aims to examine the ability of mathematical connections of students in one junior high school in Bandung on Social Arithmetic materials. The method used in this study is descriptive qualitative, with the subject of research is 36 students of class VIII in one of the State Junior High School in Bandung. Instrument given in the form of description test as much as 3 problem each representing indicator ability and analyzed so that get data fulfillment indicator ability of mathematic connection. Based on the data analysis, the students 'mathematical connection ability is still low, so it is necessary to design the learning activities that can facilitate students' mathematical connection ability.
\end{abstract}

Keywords: Ability of Mathematical Connection, Social Arithmetic, Junior High School Students

\begin{abstract}
Abstrak
Kemampuan koneksi matematik merupakan kemampuan esensial yang harus dikuasai siswa sekolah menengah, karena akan membantu penguasaan pemahaman konsep yang bermakna dan membantu menyelesaikan permasalahan matematika melalui keterkaitan antar konsep matematika dan antara konsep matematika dengan konsep dalam disiplin lain bahkan dengan aplikasi dalam kehidupan nyata siswa. Penelitian ini bertujuan untuk mengkaji kemampuan koneksi matematik siswa di salah satu SMP di Kota Bandung pada materi Aritmetika Sosial. Metode yang digunakan dalam penelitian ini adalah deskriptif kualitatif, dengan subjek penelitian adalah 36 siswa kelas VIII di salah satu SMP Negeri di Kota Bandung. Instrumen yang diberikan berupa tes uraian sebanyak 3 soal yang masingmasing mewakili indikator kemampuan dan dianalisis sehingga memperoleh data pemenuhan indikator kemampuan koneksi matematik. Berdasarkan hasil analisis data, bahwa kemampuan koneksi matematik siswa masih rendah, sehingga diperlukan kemampuan merancang kegiatan pembelajaran yang dapat memfasilitasi kemampuan koneksi matematik siswa.
\end{abstract}

Kata Kunci: Kemampuan Koneksi Matematik, Aritmetika Sosial, Siswa SMP.

How to cite: Nurhasanah, Yuliani, D., Minarti, E. D., \& Rohaeti, E. E. (2018). Hubungan dntara Kemampuan Pemahaman Matematik dengan Kemandirian Belajar Siswa SMP yang Menggunakan Pendekatan Kontekstual. JPMI - Jurnal Pembelajaran Matematika Inovatif, 1 (6), 1079-1086.

\section{PENDAHULUAN}

Matematika merupakan ilmu tentang logika mengenai bentuk, susunan, besaran, dan konsepkonsep yang berhubungan satu dengan yang lain dengan jumlah yang banyak yang terbagi dalam tiga bidang, yakni aljabar, analisis dan geometri (Suherman, 2003). Matematika merupakan ilmu dasar yang berguna bagi kehidupan manusia diantaranya yaitu matematika mendasari perkembangan teknologi modern, matematika mempunyai peranan penting dalam 
berbagai disiplin ilmu dan matematika memajukan daya pikir manusia. Sebagai ilmu yang saling berkaitan, dalam hal ini siswa diharapkan memiliki kemampuan untuk memecahkan persoalan-persoalan matematika yang memiliki kaitan terhadap materi yang dipelajari sebelumnya, memahami konsep matematika, menjelaskan keterkaitan antar konsep dan mengaplikasikan konsep atau algoritma secara luwes, akurat, efisien, dan tepat dalam pemecahan masalah matematik. Kemampuan ini disebut dengan kemampuan koneksi matematik.

Kemampuan koneksi matematik merupakan kemampuan esensial yang harus dikuasai siswa sekolah menengah. Pentingnya pemilikan kemampuan koneksi matematik terkandung dalam tujuan pembelajaran matematika sekolah menengah (NCTM, 2000), yaitu: pemecahan masalah, penalaran dan bukti, komunikasi, koneksi, dan reperesentasi matematik. Dalam rumusan tujuan tersebut, kemampuan koneksi matematik menjadi salah satu kemampuan yang harus dimiliki oleh siswa karena akan membantu penguasaan pemahaman konsep yang bermakna dan membantu menyelesaikan tugas pemecahan masalah melalui keterkaitan antar konsep matematika dan antara konsep matematika dengan konsep dalam disiplin lain bahkan dengan aplikasi dalam kehidupan nyata siswa.

Koneksi matematika merupakan suatu kegiatan pembelajaran dimana siswa dapat mendefinisikan bagaimana cara untuk menyelesaikan suatu permasalahan, situasi dan ide matematika yang saling berhubungan kedalam bentuk model matematika, serta siswa dapat menerapkan pengetahuan yang diperoleh untuk menyelesaikan dalam memecahkan satu masalah ke masalah lain (Lappan, 2002). Setiap konsep matematika berkaitan dengan konsep yang lain, begitu pula dengan yang lainnya, misalnya dalil dan dalil, antara teori dan teori, antara topik dengan topik, ataupun antara cabang matematika dengan cabang matematika lain. Siswa harus memiliki kemampuan koneksi agar dalam mempelajari matematika tidak mengingat terlalu banyak konsep dan prosedur matematika yang saling terpisah. Apabila siswa mampu mengaitkan ide-ide matematika maka pemahaman matematikanya akan lebih mendalam dan lebih tahan lama karena mereka mampu melihat keterkaitan antar topik dalam matematika, dengan konteks selain matematika, dan dengan pengalaman hidup sehari-hari. Berbagai upaya perbaikan sistem pengajaran matematika dengan pendekatan atau dengan metode pembelajaran banyak dilakukan oleh tenaga pendidik. Perbaikan tersebut bertujuan untuk membentuk sumber daya manusia Indonesia yang memiliki pemikiran kritis, sistematis, logis, kreatif dan efektif sehingga dapat mengatasi berbagai tantangan dan permasalahan yang ada (Minarti \& Nurfauziah, 2016).

Dalam pembelajaran matematika saat ini, terlihat siswa masih sulit menghubungkan materi yang mereka pelajari dengan materi prasyarat yang sudah mereka kuasai. Konsep-konsep yang telah dipelajari tidak bertahan lama dalam ingatan siswa, akibatnya kemampuan koneksi mereka belum optimal. Kesulitan ini terjadi karena matematika merupakan pelajaran yang berstruktur vertikal dimana terdapat suatu runtutan untuk mempelajari materi matematika (Hidayat, 2012).

Penelitian ini bertujuan untuk mengkaji kemampuan koneksi matematik siswa SMP di Kota Bandung pada materi Aritmetika Sosial. Aritmetika sosial merupakan salah satu materi yang dipelajari di kelas VII SMP, adapun yang menjadi pembahasan dalam bab aritmetika sosial mengenai kegiatan yang terkait dengan dunia perekonomian, antara lain: penjualan, pembelian, keuntungan, kerugian, bunga, pajak, bruto, neto, tara. Melihat materi-materi tersebut, aritmetika sosial merupakan salah satu materi yang banyak aplikasinya dalam kehidupan sehari-hari yang di masa yang akan datang akan banyak dialami oleh para siswa sendiri. Semua konsep dalam aritmetika sosial erat kaitannya dengan materi-materi yang 
sebelumnya telah dipelajari oleh siswa, sehingga diperlukan kemampuan koneksi matematik siswa yang baik.

Penelitian ini bertujuan untuk mengetahui kemampuan koneksi matematik siswa kelas VIII salah satu SMP Negeri di Kota Bandung pada materi aritmetika sosial. Adapun indikator yang digunakan untuk menganalisis kemampuan koneksi matematik yaitu mampu menerapkan konsep yang telah dipelajari sebelumnya dengan konsep yang terdapat pada aritmetika sosial. Ketika kemampuan koneksi matematik siswa diketahui, selanjutnya guru perlu merancang pembelajaranyang memfasilitasi dan membiasakan siswa untuk melakukan pengkoneksian sehingga kemampuan koneksi matematik siswa dapat meningkat.

\section{METODE}

Metode yang digunakan dalam penelitian ini adalah deskriptif kualitatif. Abdurrahman (1999) mengatakan bahwa penelitian deskriptif bertujuan untuk menggambarkan secara tepat sifatsifat suatu individu, keadaan, gejala atau kelompok tertentu. Sementara itu, Moleong (2001) mengungkapkan metode penelitian kualitatif sebagai prosedur penelitian yang menghasilkan data deskriptif berupa kata-kata tertulis atau lisan dari orang-orang dan perilaku yang dapat diamati.

Subjek dalam penelitian ini sebanyak 36 siswa salah satu SMP Negeri di Kota Bandung. Instrumen dalam penelitian ini berupa tes uraian sebanyak 3 soal dan diolah menggunakan program Microsof Excel. Tes yang digunakan berbentuk uraian, dengan maksud untuk melihat proses penyelesaian jawaban siswa sehingga diketahui sejauh mana siswa tersebut mampu mengaitkan antar konsep. Indikator kemampuan koneksi matematik yang digunakan dalam penelitian ini adalah yang dikemukakan oleh Sumarmo (2016) yaitu, (1) Mengidentifikasi hubungan berbagai representasi konsep dan prosedur matematika, (2) Mengidentifikasi hubungan satu prosedur ke prosedur lain dalam representasi yang ekuivalen, (3) Menjelaskan penerapan topik matematika dalam konten bidang studi lain atau masalah kehidupan sehari-hari.

\section{HASIL DAN PEMBAHASAN}

Sebelum penelitian dilakukan, peneliti meminta izin terlebih dahulu kepada kepala sekolah dan menentukan subjek penelitian berdasarkan rekomendasi dari guru bidang studi matematika. Setelah subjek penelitian ditetapkan, selanjutnya langkah pertama yang dilakukan pada penelitian ini yaitu menentukan materi yang akan digunakan untuk melihat kesalahan koneksi matematik siswa, mendesain dan menyusun tes kemampuan koneksi matematik siswa. Penyusunan soal tes disesuaikan juga dengan kompetensi dasar pada materi aritmetika sosial. Soal tes yang akan digunakan dikonsultasikan terlebih dahulu kepada dosen pembimbing. Tes diberikan kepada 36 siswa dan dikerjakan selama 45 menit. Selanjutnya data akan diolah dan dianalisis berdasarkan rubric penilaian tes.

Soal tes sebanyak tiga buah berbentuk soal cerita pada materi aritmetika sosial. Soedjadi (2000) menyatakan bahwa dalam menyelesaikan soal cerita, langkah yang harus dilakukan yaitu: (1) menuliskan apa yang diketahui dan ditanyakan dalam soal, (2) membuat model matematika, (3) menyelesaikan model matematika, dan (4) mengembalikan jawaban model matematika kepada jawaban soal aslinya. Langkah penyelesaian poin (1) dan (2) termasuk kedalam indikator koneksi matematik mengenali ide-ide matematik. Poin penyelesaian soal cerita ke (3) dan (4) termasuk ke dalam indikator koneksi menggunakan hubungan diantara ide-ide matematika. Jika 4 poin tersebut dapat dipenuhi oleh siswa, maka siswa tersebut memenuhi indikator koneksi matematik yaitu 
memahami bagaimana ide matematik saling berhubungan dan membangun satu sama lain untuk menghasilkan keseluruhan yang koheren.

Adapun soal nomor 1 ditampilkan sebagai berikut,

1. Santi mempunyai tabungan sebesar Rp.12.500.000,00 dengan uang tersebut ia membeli sebuah laptop seharga Rp. 7.500.000,00. Nino adalah adik Santi, ia membeli sepeda dengan harga $\mathrm{Rp}$. 2.500.000,00 dengan meminjam uang tabungan Santi. Setelah beberapa hari Nino teriatuh dari sepeda dan ia ingin menjual sepedanya, berbarengan dengan Santi yang akan menjual laptop yang baru dibelinya juga, jika Santi ingin mendapat keuntungan sebesar $5 \%$ dari hasil menjual laptopnya, sedangkan Nino ingin mendapat keuntungan dari menjual sepedanya itu sebesar 2\%. Berapakah jumlah keseluruhan uang tabungan Santi setelah menjual laptop dan sepeda tersebut? (Mengidentifikasi hubungan berbagai representasi konsep dan prosedur matematika)

\section{Gambar 1. Soal Penelitian Nomor 1}

Berdasarkan hasil analisis dari jawaban siswa untuk nomor 1, siswa diminta menentukan jumlah tabungan setelah proses jual beli yang dilakukan. Berdasarkan hasil analisis, diketahui 2 siswa atau 5,55 \% memporeleh skor 0, 15 siswa atau 41,6 \% memperoleh skor 1, 12 siswa atau 33,3\% memperoleh skor 2, 7 siswa atau 19,4\% memperoleh skor 3 dan tidak ada sama sekali siswa yang memperoleh skor maksimal yakni 4 .

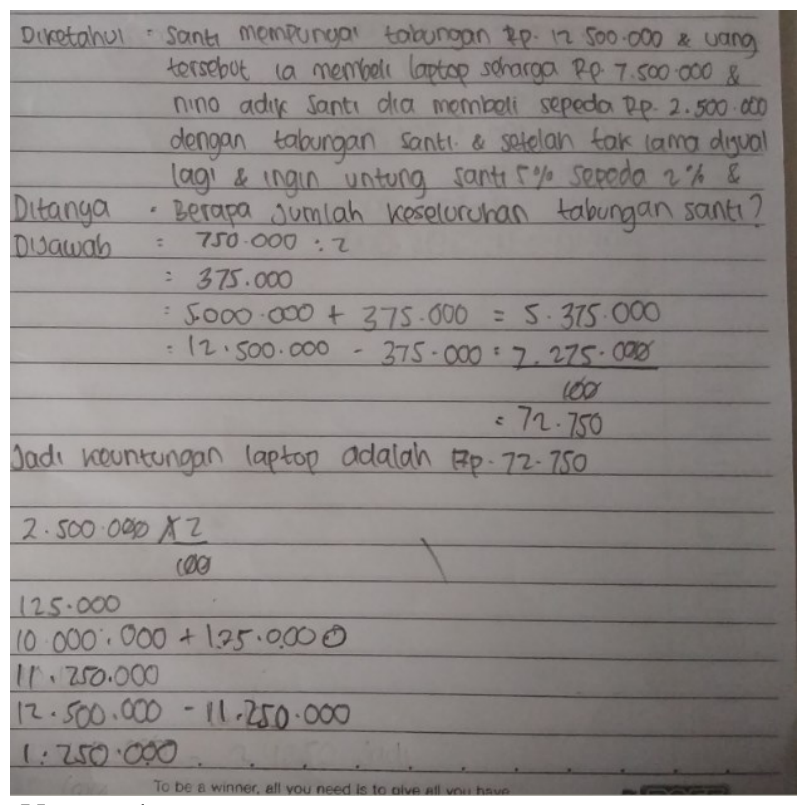

\section{Gambar 2. Jawaban Siswa Nomor 1}

Pada soal tersebut siswa tidak dapat memahami maksud soal dan keliru dalam melakukan perencanaan perhitungan sehingga jawabannya belum benar. Hal ini menunjukkan bahwa kemampuan koneksi matematik siswa dalam mengidentifikasi hubungan berbagai representasi konsep dan prosedur matematika masih tergolong rendah. Hal ini sesuai dengan yang diteliti oleh Linto, Elniati, \& Rizal (2012) yang mengemukakan bahwa rendahnya indikator ini dikarenakan siswa tidak terbiasa menghubungkan matematika dengan kehidupan sehari-hari mereka. Hal ini juga sejalan dengan hasil penelitian Muncarno (2008) yang menyimpulkan bahwa siswa mengalami kesulitan dalam memahami soal disebabkan karena siswa kurang 
cermat dalam membaca dan memahami kalimat demi kalimat, mengenai hal yang diketahui, ditanyakan, serta cara menyelesaikan soal secara tepat.

Berikut tampilan soal nomor 2,

2. Seorang pedagang ayam membeli 320 ekor ayam dari petemak dengan harga rata-rata Rp.7.000,00 yang kemudian dijualnya di pasar. Pada hari pertama ia menjual 190 ekor ayam dengan harga Rp. $12.000,00$ tiap ekor. Termyata pada hari kedua 110 ekor ayam mati karena flu burung dan sisanya berhasil dijual dengan harga Rp.9.000,00 tiap ekor. Berapa persentase keuntungan/ kerugian yang dialami pedagang tersebut? (Mengidentifikasi hubungan satu prosedur ke prosedur lain dalam representasi yang ekuivalen)

\section{Gambar 3. Soal Penelitian Nomor 2}

Untuk analisis jawaban siswa pada soal nomor 2, siswa diminta menentukan persentase keuntungan yang diperoleh pedagang. Berdasarkan hasil analisis, diperoleh data sebanyak 7 siswa atau 19,4\% memperoleh skor 0, 24 siswa atau 66,67 \% memperoleh skor 1, 4 siswa atau $11,1 \%$ memperoleh skor 2, 1 siswa atau 2,77 \% siswa memperoleh skor 3 dan tidak ada siswa yang memperoleh skor 4 .

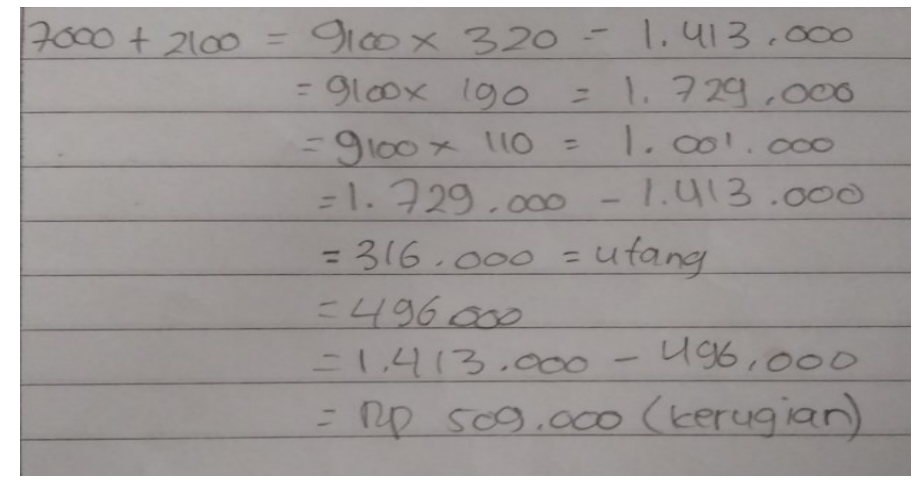

\section{Gambar 4. Jawaban Siswa Nomor 2}

Hal ini menunjukkan bahwa kemampuan koneksi matematik siswa dalam mengidentifikasi hubungan satu prosedur ke prosedur lain dalam representasi yang ekuivalen masih rendah. Kesulitan yang dihadapi siswa dari indikator ini adalah siswa tidak bisa memahami hubungan dari prosedur atau proses pertama ke proses selanjutnya yang saling berkaitan sehingga ketika siswa melanjutkan tahapan selanjutnya sudah pasti salah sampai akhir jawaban yang diperoleh siswa. Sehingga persentase yang diperoleh sangat rendah. Hal tersebut sejalan dengan hasil penelitian Ruspiani (2000) dan Lestari (2013) masing-masing mengungkapkan bahwa kemampuan terendah siswa ada pada kemampuan koneksi antar topik matematika. Rendahnya tingkat kemampuan koneksi antar topik, dibandingkan dengan koneksi matematika dengan disiplin ilmu lain dan koneksi dengan dunia nyata, antara lain karena banyaknya topik matematika yang harus dikaitkan dengan penyelesaian soal sehingga memerlukan jangkauan pemikiran yang tinggi. Sedangkan pada koneksi dengan dunia nyata, permasalahn utamanya adalah kesulitan dalam membuat model matematika. Kusmayadi (2011) juga mengemukakan bahwa kebanyakan siswa tidak mengetahui dan tidak mengerti materi mana yang ada hubungannya dengan materi yang akan dipelajari. Selain itu, menurut Budiyono (2008) jenisjenis kesalahan yang dilakukan siswa dalam menyelesaikan soal matematika yaitu kesalahan 
konsep, meliputi (1) kesalahan menentukan teorema atau rumus untuk menjawab masalah, (2) penggunaan rumus atau teorema oleh siswa tidak sesuai dengan kondisi prasyarat berlakunya rumus tersebut. Berdasarkan fakta tersebut semua siswa tidak dapat menyelesaikan soal nomor 2. Pada soal nomor 2, indikator koneksi matematik tidak terpenuhi.

Koneksi matematis mengacu kepada pemahaman yang mengharuskan siswa dapat mernperlihatkan hubungan antara topik matematika. Sedangkan hubungan eksternal matematika meliputi hubungan antara matematika dengan bidang studi lain dan dengan kehidupan sehari-hari. Dalam pembelajaran matematika kemampuan menghubungkan suatu materi yang satu dengan materi yang lain atau dengan kehidupan sehari-hari berperan penting dalam proses pembelajaran dalam hal ini pembelajaran matematika. Melalui kemampuan koneksi matematis, kemampuan berfikir siswa terhadap matematika diharapkan dapat menjadi semakin luas. Selain itu, koneksi matematis dapat pula meningkatkan kemampuan kognitif siswa seperti mengingat kembali, memahami penerapan suatu konsep terhadap lingkungan dan sebagainya (Minarti \& Nurfauziah, 2016)

Berikut tampilan soal nomor 2,

3. Klara dan Nania mulai menabung pada salah satu bank didekat rumahnya.

Mereka mulai menabung pada tanggal 12 Oktober 2017, jumlah awal tabungan

Klara sebesar Rp.2.000.000,00 dan jumlah tabungan Nania Rp.4.000.000,00

dengan bunga $9 \%$ setiap tahunnya. Jika Klara setiap 4 hari sekali menabung

Rp. $200.000,00$ dan Nania setiap 6 hari sekali menabung Rp250.000,00

Berapakah jumlah tabungan mereka masing-masing ketika mereka bertemu lagi untuk pertama kalinya? (Menjelaskan penerapan topik matematika dalam konten

bidang studi lain atau masalah kehidupan sehari-hari)

\section{Gambar 5. Soal Penelitian Nomor 3}

Sedangkan analisis jawaban siswa pada nomor 3, siswa diminta mengaitkan konsep aritmetika sosial dengan konsep kelipatan persekutuan serta penerapannya dalam kehidupan sehari-hari. Berdasarkan hasil analisis diperoleh data sebanyak 16 siswa atau 44,4\% memperoleh skor 0 , 17 siswa atau 47,2 \% memperoleh skor 1, 3 siswa atau 8,4 \% memperoleh skor 2, dan tidak ada siswa yang memperoleh skor 3 dan 4 .

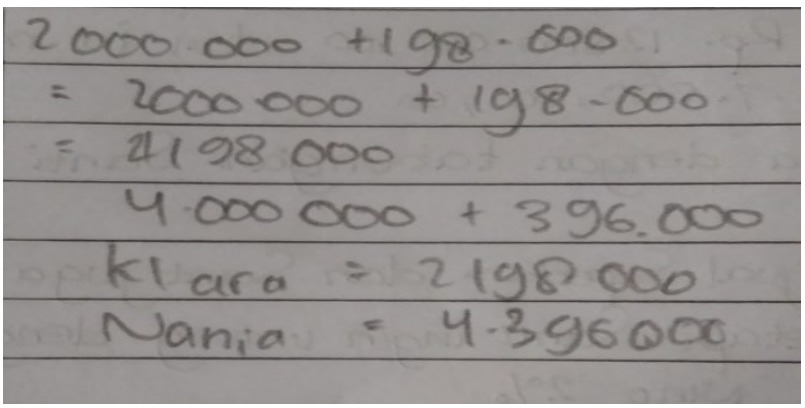

\section{Gambar 6. Jawaban Siswa Nomor 3}

Hal ini menunjukkan bahwa persentase kemampuan koneksi matematik siswa dalam menjelaskan penerapan topik matematika dalam konten bidang studi lain atau masalah kehidupan sehari-hari sangat rendah. Untuk indikator memahami bahwa ide matematika saling terhubung dan membangun satu sama lain untuk menghasilkan keseluruhan yang koheren, siswa juga masih banyak yang mengalami kesalahan. Hal ini sejalan dengan Rohendi \& Dulpaja (2003) menyatakan bahwa dengan koneksi matematik, siswa dapat menghubungkan ide-ide matematik yang akan memfasilitasi kemampuan mereka untuk merumuskan dan memverifikasi dugaan antara topik dalam matematika. Kesulitan yang dihadapi siswa untuk indikator ketiga ini sangat kompleks dimana pada soal ini permasalahan 
yang disajikan memiliki beberapa tingkat kesulitan, yang menyebabkan siswa tidak memahami konsep yang harus diterapkan dan tidak mampu mengaitkan tahapan pertama ketahapan selanjutnya yang berhubungan dengan permasalahan diluar konteks bahasan yang disajikan sehingga persentase yang diperoleh sangat rendah.

Lestari, Rohaeti, \& Purwasih (2018) mengemukakan bahwa untuk mencapai kemampuan koneksi dalam matematika bukanlah suatu hal yang mudah karena kemampuan untuk mengkoneksikan dalam matematika dilakukan secara individual. Setiap peserta didik mempunyai kemampuan yang berbeda dalam mengkoneksikan hubungan dalam matematika. Namun demikian peningkatan kemampuan koneksi matematis siswa perlu diupayakan dan dicarikan suatu alternative untuk membantu guru di dalam meningkatkan kemampuan koneksi matematis. Untuk mencapai hasil yang diharapkan dari kemampuan koneksi matematik siswa adalah mampu memahami konsep yang akan diterapkan pada permasalahan yang diberikan, mampu memahami soal dengan baik sehingga ketika jawaban dari soal yang diberikan saling berkaitan antara proses atau tahapan yang satu dengan tahapan berikutnya bisa diselesaikan dengan benar sampai jawaban akhir, dan untuk selanjutnya harus mampu mengkaitkan permasalahan matematika dengan permasalahan diluar matematika atau dalam kehidupan sehari-hari.

\section{KESIMPULAN}

Berdasarkan hasil kajian dan pembahasan, maka dapat disimpulkan kemampuan koneksi matematik siswa kelas VIII di salah satu SMP Negeri di Kota Bandung dalam menyelesaikan soal aritmetika sosial masih rendah. Hal tersebut ditunjukkan dengan hasil tes kemampuan koneksi matematik yang diberikan, dimana lebih banyak siswa tidak dapat memahami soal dengan baik, dan tidak dapat menerapkan konsep yang telah dipelajari sebelumnya sehingga siswa kesulitan dalam menyelesaikan soal. Hasil penelitian ini diharapkan dapat memberikan informasi kepada pembaca mengenai kemampuan koneksi matematik siswa. Mengingat pentingnya kemampuan koneksi matematik dan fakta mengenai kemampuan koneksi matematik siswa yang masih rendah, diperlukan kemampuan merancang kegiatan pembelajaran yang dapat memfasilitasi kemampuan koneksi matematik siswa. Untuk peneliti selanjutnya dapat meneliti kemampuan matematik yang lain atau meneliti kemampuan koneksi matematik pada materi matematika lainnya.

\section{UCAPAN TERIMA KASIH}

Kami ucapkan terimakasih kepada SMP Negeri 25 Bandung yaitu Kepala Sekolah, Ibu Guru mata pelajaran matematika yang telah memberikan izin untuk penelitian di kelas VIII. Untuk dosen pembimbing yang telah membimbing kami dalam menyelesaikan jurnal, dan untuk teman-teman yang sudah membantu dan memberi dukungan.

\section{DAFTAR PUSTAKA}

Abdurrahman, S. (1999). Metode Penelitian Suatu Pemikiran dan Penerapan. Jakarta: PT. Rineka Cipta.

Budiyono. (2008). Kesalahan Mengerjakan Soal Cerita dalam Pembelajaran Matematika. Jurnal Penelitian Pendidikan, 11(1).

Hidayat, W. (2012). Meningkatkan Kemampuan Berpikir Kritis Dan Kreatif Matematik Siswa 
1086 Nurhasanah, Yuliani, Minarti \& Rohaeti, Kajian Kemampuan Koneksi Matematik Siswa...

Sma Melalui Pembelajaran Kooperatif Think-Talk-Write. Prosiding Seminar Nasional Penelitian, Pendidikan dan Penerapan MIPA, 1-10.

Kusmayadi. (2011). Pembelajaran Matematika Realistik untuk Meningkatkan Kemampuan Komunikasi dan Pemecahan Masalah Matematis Siswa SMP. Tesis SPS UPI Bandung: tidak diterbitkan.

Lappan, G. (2002). Getting to Know Connected Mathematics An Implementations Guede. New Jerssey.

Lestari, R. S., Rohaeti, E. E., \& Purwasih, R. (2018). Profil Kemampuan Koneksi Matematis Siswa SMP dalam Menyelesaikan Soal Bangun Ruang Sisi Datar Ditinjau dari Kemampuan Dasar. Jurnal Ilmiah Pendidikan Matematika, Volume 3 N.

Lestari, K. E. (2013). Implementasi Brain-Based Learning untuk Meningkatkan Kemampuan Koneksi dan Kemampuan Berpikir Kritis Matematis Siswa Sekolah Menengah Pertama. Tesis SPS UPI Bandung: tidak diterbitkan.

Linto, R. L., Elniati, S., \& Rizal, Y. (2012). Kemampuan Koneksi Matematis Dan Metode Pembelajaran Quantum Teaching Dengan Peta Pikiran. Jurnal Pendidikan Matematika, Part, 1(2), 83-87. https://doi.org/10.13989/j.cnki.0517-6611.2015.10.011

Minarti, E.D., Nurfauziah, P. (2016). Pendekatan konsturktivisme Dengan Model Pembelajaran Generatif Guna Meningkatkan Kemampuan Komunikasi Dan Koneksi Matematis Serta Self Efficacy Mahasiswa Calon Guru Di Kota Cimahi. Jurnal Ilmiah UPT P2M STKIP Siliwangi,Vol.3, No.

Moleong, L. J. (2001). Metode Penelitian Kualitatif. Bandung: Remaja Rosdakarya.

Muncarno. (2008). Penerapan Model Penyelesaian Soal Cerita Dengan Langkah-Langkah Pemecahan Masalah Untuk Meningkatkan Prestasi Belajar Matematika Siswa Kelas I SMP. Lampung: LPMP Universitas Lampung.

NCTM. (2000). Principles and standards for School Mathematics. Reston. Retrieved from va: Authur. http://educare.e-fkipunla.net. Diakses: 12 Mei 2014

Rohendi, D \& Dulpaja, J. (2003). Connected Mathematics Project (CMP) Model Based on Presentation Media to the Mathematical Connection Ability of Junior High School Student. Journal of Education and Practice. Journal of Education and Practice, 4(4), 1722.

Ruspiani. (2000). Kemampuan dalam Melakukan Koneksi Matematika. Tesis pada PPs UPI: tidak diterbitkan.

Soedjadi. (2000). Kiat Pendidikan Matematika di Indonesia. Jakarta: Depdiknas.

Suherman. (2003). Strategi Pengajaran Matematika Kontemporer. Bandung : JICA.

Sumarmo. (2016). Pedoman Pemberian Skor pada Beragam Tes Kemampuan Matematik. Bandung: Pendidikan Matematika STKIP Siliwangi Bandung. 